\title{
Performance of the fat-tailed Barbarine sheep in its environment: adaptive capacity to alternation of underfeeding and re-feeding periods. A review
}

\author{
Naziha ATTI $^{\mathrm{a} *}$, François BOCQUIER ${ }^{\mathrm{b}}$, Gley KHALDI ${ }^{\mathrm{c}}$ \\ ${ }^{a}$ INRA-Tunisie, Laboratoire de Productions Animales et Fourragères, rue Hédi Karray, \\ 2049 Ariana, Tunisia \\ b UMR ERRC, Agro.M-INRA Montpellier, 2 place Viala, 34060 Montpellier Cedex 1, France \\ ${ }^{c}$ INAT, 43 avenue Charles Nicolle, 1002 Tunis, Tunisia
}

(Received 10 April 2003; accepted 9 March 2004)

\begin{abstract}
The Barbarine sheep is characterised by a fat-tail, whose mass varies between 1 and $4 \mathrm{~kg}$. Its management is traditionally based on spring mating. The ability of this fat-tailed ewe to mobilise its body reserves has been demonstrated in lactation and the dry period by experimentally varying the food supply. The severely underfed ewe ( $200 \mathrm{~g}$ oat hay) can survive 161 days and lose $36 \%$ of its body weight (BW), with a change of $8.8 \mathrm{~kg}$ of dissected adipose tissue (AT) and $3.4 \mathrm{~kg}$ of muscle. It reached this stage with an empty BW of $24 \mathrm{~kg}$ containing $12 \%$ of AT. The fat tail exerts a role as a body reserve mainly through its mass rather than through its ability to be rapidly mobilised. In such situations, plasma NEFA and 3-hydroxybutyrate concentrations are first almost doubled, then decline in permanently underfed ewes, showing the ability of Barbarine ewes to adjust their lipid metabolite concentration in order to limit the toxic effects of high concentrations and therefore prolong survival. By the end of a re-feeding period, Barbarine ewes returned to their initial BW, lipid and protein mass. This breed has a good fertility, which can, however, be depressed in cases of undernutrition. However, if the mating period is extended, the overall reproductive performance is generally satisfactory. Poor nutrition during pregnancy may reduce lamb birth weight and affect subsequent growth, however, in traditional conditions, ewe and lamb mortality rates are surprisingly low in this breed. In normal birth weighted lambs, the post-weaning growth performances of grazing lambs are moderate but in feedlot conditions the conversion rate is rather low and carcass adiposity is high. This review shows that the Barbarine sheep, and specially the ewe, is well adapted to the local conditions mainly because of its high fertility and its ability to deposit and mobilise body reserves.
\end{abstract}

fat-tailed sheep / body reserves / undernutrition / ewe reproductive performances / lamb growth performances

Résumé - Performance des ovins de race Barbarine à queue grasse dans leur environnement : capacité d'adaptation à l'alternance de périodes de sous-alimentation et de réalimentation. La race Barbarine est caractérisée par une queue grasse dont la masse varie de 1 à $4 \mathrm{~kg}$. Le système traditionnel d'élevage de la Barbarine est basé sur la lutte de printemps. La capacité de mobilisation des réserves chez cette brebis a été démontrée, aussi bien sur brebis allaitantes que sur brebis taries,

* Corresponding author: belhaj.naziha@iresa.agrinet.tn 
en faisant varier expérimentalement les apports alimentaires. Des brebis sévèrement sous-alimentées ( $200 \mathrm{~g}$ de foin d'avoine par $\mathrm{j}$ ) survivent 161 jours en perdant $36 \%$ de leur poids vif initial (PV), avec $8,8 \mathrm{~kg}$ de tissus adipeux (TA) et de 3,4 kg de muscle. Elles atteignent cet état avec un PV vide de $24 \mathrm{~kg}$ contenant $12 \%$ de TA. Le gras caudal agit comme réserve corporelle plutôt par sa masse que par son aptitude à être mobilisé rapidement. Dans de telles conditions, les concentrations plasmatiques en AGNE et 3-hydroxybutyrate sont transitoirement doublées puis elles déclinent, chez les brebis toujours sous-alimentées, montrant la capacité de la Barbarine à ajuster la concentration des métabolites lipidiques pour limiter les effets toxiques des fortes concentrations et prolonger la survie. En fin de période de réalimentation, les brebis Barbarine retournent à leur PV et masses lipidique et protéique initiales. Cette race a une fertilité satisfaisante, qui peut diminuer en cas de sous-nutrition. Cependant, si la période de lutte est suffisamment longue, la fertilité s'améliore. La sous-nutrition durant la gestation peut entraîner une réduction du poids des agneaux à la naissance. Cependant et dans de telles conditions, le taux de mortalité des agneaux est étonnamment faible. Chez des agneaux à poids de naissance normal, la croissance post-sevrage est modérée au pâturage mais, en bergerie, elle reste faible avec une efficacité alimentaire particulièrement basse et une adiposité élevée. Cette revue montre que la brebis de race Barbarine est bien adaptée aux conditions locales en raison de sa bonne fertilité et sa capacité à déposer et mobiliser des réserves corporelles.

ovin à queue grasse / réserves corporelles / sous-alimentation / performances de reproduction des brebis / performances de croissance des agneaux

\section{INTRODUCTION}

The sheep is a major livestock resource throughout North Africa and Near East regions. Its production is a main occupation for people working in agriculture. Sheep produce meat, milk and fibre and provide in many countries, a very important flexible financial reserve and play important social and cultural roles. Most sheep are raised under a pastoral or agro-pastoral system, in which the low cost feeding (grazing of poor rangelands, stubble, fallow) is general and supplementation, although with an increasing trend, is still limited [26, 34, 25]. The fat-tailed breeds represent the great majority of sheep breeds in most of this area (from west Asia into Tunisia). Fat-tailed sheep have been bred in west Asia for at least 5000 years [24]. In Tunisia, the main breed is the fat-tailed Barbarine, which was introduced about $400 \mathrm{BC}$ and was later re-introduced $(900$ AD) with Arab invasions coming from the Near-East [43]. Hence, fat-tailed breeds are localised in non-temperate regions, so they are subject to large seasonality of vegetations production and wide variability of feed resource availability. Food shortage, often associated with a poor quality of the available food is very fre- quent. Food shortage also occurs in temperate regions: feeding conditions in the winter are as harsh, but in these regions, conserved forages (hay, silage) are available and owners traditionally breed animals indoor and give them concentrate feeds during this period of the year [13]. Inversely, in arid and semi-arid areas, grazing is the main feeding mode but vegetation production is not guaranteed in all seasons or every year. In case of grazing shortage, owners have to move with their flock looking for grass in more favourable places. When moving is not possible, animals have to draw their body reserves in order to survive. In such situations, the sheep farming systems have been fitted in order to make periods of production coincide with periods of food availability. The important role of body reserve can, however, be efficient only if ewes have the opportunity to replenish these body reserves during more favourable periods and/or when their requirements are low in order to be able to enter another productive cycle. This ability of fat-tailed sheep to cope with periods of food shortage is the result of a long evolutionary process in natural harsh conditions. Furthermore, within a flock the level of underfeeding is not constant due to the great variability of requirements and 
competition between animals [15]. In such a situation, all the adaptive mechanisms, including body fat and protein mobilisation, are obviously of considerable importance in determining animal productivity and, in many instances, its survival. The aim of this review was to analyse the adaptive mechanisms that occur in underfed Barbarine sheep and summarise the accumulated knowledge that demonstrates the ability of this animal to contribute to the meat production in the Tunisian context, reviewing the results on the peculiarity of both the ewe and lamb.

\section{BARBARINE CHARACTERISTICS AND REARING}

The Barbarine sheep is a middle sized animal with a height ranging between 60 and $80 \mathrm{~cm}$ in males and 55 and $70 \mathrm{~cm}$ in females. The body weight varies considerably according to nutritional conditions, it ranges between 45 and $85 \mathrm{~kg}$ in rams and 28 and $65 \mathrm{~kg}$ in ewes [34]. This breed of sheep is characterised by its fat tail, whose weight varies according to food availability from 1 to $4 \mathrm{~kg}$ [8], with 16 and 19\% of total adipose tissue (AT). The Barbarine fattailed ewe has a similar size and BW as the Rasa Aragonesa Spanish thin-tailed ewe but the Barbarine is fatter than the Rasa Aragonesa. The Barbarine's total AT is systematically higher than that of the Rasa Aragonesa whatever BW or body condition score (BCS). For an empty body weight (EBW) of 50 or $25 \mathrm{~kg}$, AT represent 39.8 or $14.8 \%$ in the Barbarine and only $32.8 \%$ and $6.5 \%$ in the Rasa Aragonesa ewe [4]. Hence, due to this extra body fat reserve the Barbarine sheep is generally considered well adapted to uncertainties of the climate and its direct consequences on feed resource availability.

The reproduction of Barbarine ewes is, as in most sheep breeds, seasonal and photoperiodically controlled; maximum oestrus activity naturally occurs in the autumn [28]. However, like most breeds from the Medi- terranean area, the effect of photoperiod on the seasonality of reproduction is limited, both in the duration of the anoestrus period and in the proportion of ewes in anoestrus at a given period $[29,34,40]$. This makes the traditional spring (April-May) mating season (i.e. out of season) of Barbarine ewes in Tunisia possible. Even if ewes are not in their physiological season for reproduction at this period, food supply is generally sufficient for an efficient reproduction. This reproduction system is aimed at ensuring that lambs born from this mating period, i.e. in the autumn, can be fattened during the following spring, the season of vegetation abundance. However, in practical conditions, the mating season is lengthened from April up to November in most flocks, so lambing occurs from September to March with a main peak in the autumn (October) and another peak in the spring (FebruaryMarch). As a consequence to spring mating, the late pregnancy and early lactation stages correspond to the late summer and early autumn, which are the most difficult periods, particularly in the dry year, but lamb fattening occurs in the spring. As the mean reproductive performance, the Barbarine fertility rate is generally high $(>90 \%)$ but the prolificacy is modest with a mean value of $115 \%$ [36].

In order to better characterise the Barbarine sheep, numerous experiments with specific measurements on ewes at different physiological stages were conducted at INRAT with the aim of studying the dynamics of body reserves under controlled feeding conditions. First it was established [3] that the maintenance energy requirements (MER) expressed in $\mathrm{g}$ of digestible organic matter (DOM) per $\mathrm{kg}$ of metabolic body weight $\left(\mathrm{BW}^{0.75}\right)$ of thin-tailed ewes $(26 \mathrm{~g})$ is close to the value obtained [13] in Barbarine ewes $27 \mathrm{~g} \mathrm{DOM} \cdot \mathrm{kg} \mathrm{BW}^{-0.75}$. The constancy in MER resulted from the same importance in all breeds of splanchnic tissues, particularly the gut, whose requirements represent a major part of MER [37]. Furthermore, it was shown that in the long term underfed Barbarine ewe, MER could 


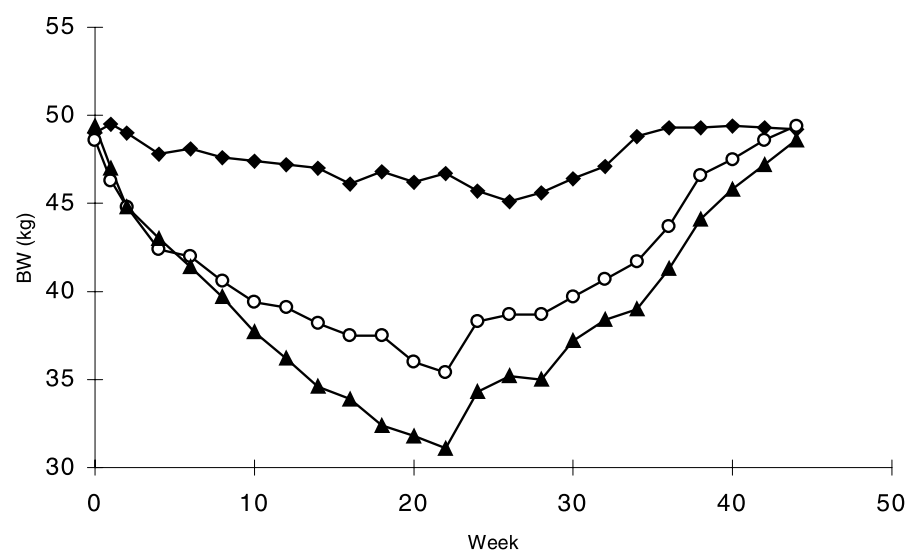

Figure 1. Body weight evolution in Barbarine dry ewes fed continuously near maintenance (v) or subjected to a constant low energy supply for 22 weeks $(20 \%(\sigma)$ or $40 \%(\mu)$ MER), then fed at $130 \%$ MER [10].

be reduced. Such an adaptation to underfeeding, by reducing MER, can be explained in Barbarine ewes by a similar decrease of the gut weight [10] as reported in other breeds.

\section{BODY RESERVE IMPORTANCE IN ANIMAL SURVIVAL}

\subsection{Body weight and body condition score variation}

Barbarine ewes, under traditional management, are subjected to large variations in BW and body fatness related to fluctuations in food supply. Severely under-nourished (20\% MER; 200 g per d oats hay) Barbarine dry ewes can lose up to $36 \%$ of their initial BW (i.e. $17 \mathrm{~kg}$ ) until one of them died (Fig. 1), after 161 days [8]. An even greater loss $(42 \% \mathrm{BW})$ is observed over a shorter period of 62 days with complete fasting [35]. In Lacaune (thin-tailed) ewes [14] receiving 30 to $40 \%$ of their MER, this loss can reach $30 \%$ of BW but the first case of mortality occurred after 63 days. Furthermore, in severely underfed Romney ewes (150 g per d alfalfa hay) [30], the mortality rate was far higher (i.e. 18\%) in a shorter time (between 29 and 42 days) of the experiment. Altogether, this clearly shows the greater ability of Barbarine ewes to survive in comparable adverse nutritional situations. In these conditions, with the scoring of either the lumbar region (BCS-L, [41]) or the tail region (BCS-T, [2]), the same tendency was observed with BCS (Fig. 2). By the end of the underfeeding period, ewes have very low mean BCS, both in the lum$\operatorname{bar}(0.68$ points $)$ and in the tail regions ( 1.88 points). Some ewes are able to reach BCS as low as 0.25 BCS-L and 0.75 BCS-T.

When re-alimented with diets based on hay $(900 \mathrm{~g}$ per d) plus a large amount of concentrate (500 g per d), these ewes are able to reach their initial $\mathrm{BW}$ and $\mathrm{BCS}$ in 154 days [8]. For a faster recovery of BW in 70 days, diets with more concentrate can be successfully used [35].

\subsection{Body tissue evolution}

In case of restriction of the energy supply, non-gut tissues are generally mobilised in the following order: fat, muscle and then bone, which is the reverse of the order of deposition, with the latest maturing tissues relatively more sensitive because of a higher 

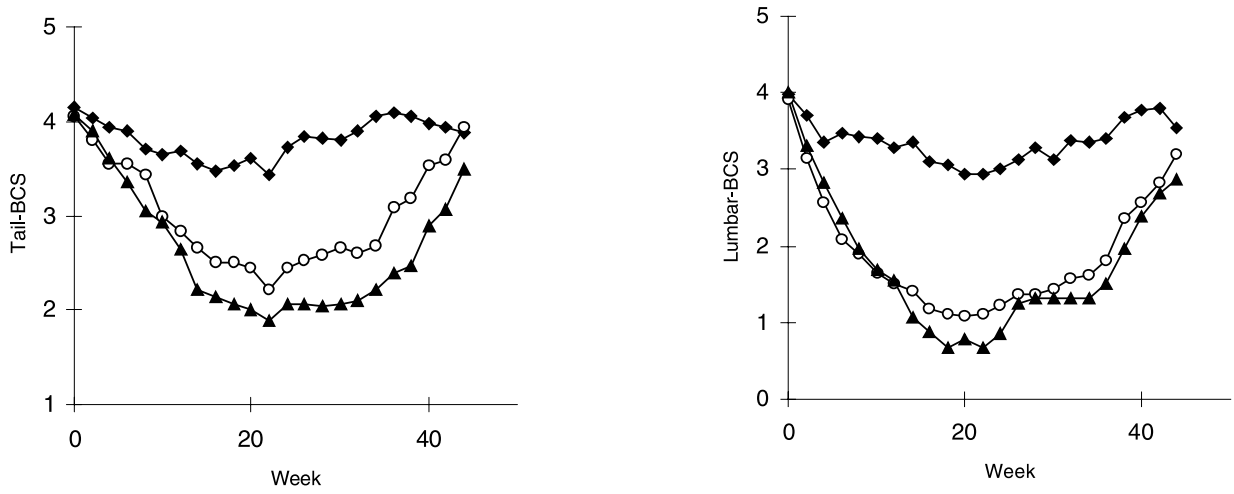

Figure 2. Body condition score (BCS) evolution in Barbarine dry ewes fed continuously near maintenance $(v)$ or subjected to a constant low energy supply for 22 weeks $(20 \%(\sigma)$ or $40 \%(\mu)$ MER), then fed at $130 \%$ MER [10].

physiological priority. Our measurements confirmed this tendency in Barbarine ewes: adipose tissues are broadly mobilised in this order: subcutaneous, perirenal, omental plus mesenteric, intermuscular and intramuscular. This is basically unaltered by differences in physiological status, as previously shown after an underfeeding of dry or lactating cows [18, 39]. This has been confirmed in both thin-tailed [44] and Barbarine ewes [4, 8]. Severely underfed dry Barbarine ewes (receiving 20\% of MER) can lose up to $70 \%$ of their initial AT mass $(8.8 \mathrm{~kg})$. In these conditions, Barbarine ewes were also able to mobilise part of their muscular mass $(3.4 \mathrm{~kg})$ and reach 161 days of under nutrition with an EBW of $27 \mathrm{~kg}$ containing $12 \%$ of AT. At the same EBW, a Rasa Aragonesa ewe would have only $6.5 \%$ AT [44] whose proportion closed on the minimum threshold of AT content (2-3\%) necessary for live [38]. If we hypothesise that the allometric coefficient of AT with EBW is constant, the Barbarine ewe would reach this threshold when the EBW is $14 \mathrm{~kg}$, which is unrealistically low. This phenomenon, also contributes to the higher ability of the Barbarine ewe to undergo a high level of underfeeding. Furthermore, in Barbarine ewes, the supplementary fat deposited in the tail has been shown to have a priority equivalent to that of omental and mesenteric fat tissues [4, 8]. Both the absolute contribution of different AT and their relative priority to be mobilised have to be considered. The subcutaneous fat, the main reserve of fat, is the most labile, and contributes quantitatively more than other fat tissues. The fat tail exerts its role as a body reserve mainly through its mass rather than through its ability to be rapidly mobilised, hence, insuring a fairly constant rate of mobilised fat, which is derived into energy during long term underfeeding.

In terms of chemical components, this tissue loss corresponds to a loss of $6.5 \mathrm{~kg}$ of lipids and $1.4 \mathrm{~kg}$ protein in $161 \mathrm{~d}$ (i.e. $42 \mathrm{~g}$ of lipid per d). The lipid weight was initially $11 \mathrm{~kg}$ (29\% of EBW) and declined to $4.3 \mathrm{~kg}$ (19\% EBW) after undernutrition indicating that $64 \%$ of body lipids were mobilised [9]. These values were similar to those reported by Panaretto [38] in thin-tailed ewes $(1.6 \mathrm{~kg}$ in $142 \mathrm{~d}$ and $2.4 \mathrm{~kg}$ of lipids in $180 \mathrm{~d}$ ).

The tissue reconstitution, during the refeeding period follows the inverse order cited above. The recovery of fat reserves can be complete after 154 days of re-feeding [8]. Studies on the fattening of culled dairy cows suggests that they may not regain all of the body muscle mobilised and thus may not be able to avoid a decline in muscle mass 
and muscle/bone ratio with ageing [39]. However, Barbarine ewes can fully recover muscles and proteins, following severe undernutrition by the end of a re-feeding period [9]. This suggests that in Barbarine ewes, body protein may be considered as a potential reserve.

As well as in other tissues, the weight of splanchnic ones, in the particular rumen, intestine and liver (gut), are decreased in underfed Barbarine ewes [10], this decrease in gut mass leads to a decrease in MER and contributes to the adaptation of these animals to a food shortage.

\section{METABOLIC ADAPTATION TO UNDER NUTRITION}

In underfed animals, the mobilisation of lipids from adipose tissues is due to the fatty acids drain that can be measured in the plasma as a non-esterified form (NEFA: non-esterified fatty acids). The circulating NEFA of underfed lactating ruminants are not always very high, because of the high rate use of NEFA by the mammary gland that allows a greater expression of the AT lipolytic potential without a major increase in plasma NEFA concentrations [20, 21]. However, in the case of the lactating Barbarine ewe, the circulating levels of NEFA are quite high [6] because of the high rate of NEFA release from adipose tissue, this can be related to the fact that for the same EBW, the level of fat reserve is usually higher in the Barbarine than in the thin Rasa Aragonesa ewe [4].

Compared to the maintenance feeding level, a moderate undernutrition of ewes (i.e. $40 \%$ MER), leads to a very similar short-term blood metabolite evolution in Barbarine [9] and in thin-tailed ewes (Bocquier et al., unpublished data): plasma NEFA concentration is constant and around $0.4 \mathrm{mM}$ during 3 to 4 weeks. When food intake is kept constant in Barbarine ewes, NEFA concentration declines regularly to half of its initial value $(0.2 \mathrm{mM})$. In the case

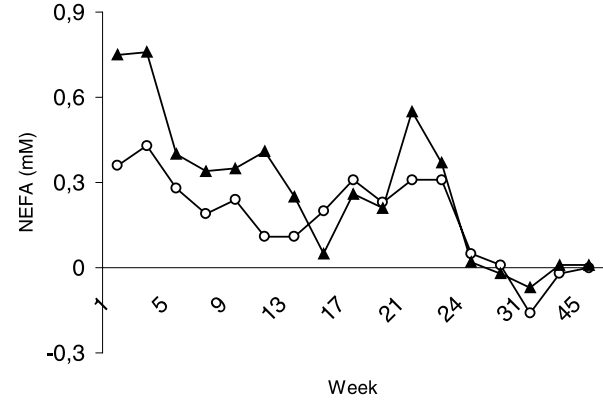

Figure 3. Pattern of non esterified fatty acids (NEFA) evolution in dry Barbarine ewes subjected to a constant low energy supply for 22 weeks $(20 \%(\sigma)$ or $40 \%(\mu)$ MER) then fed at $130 \%$ MER: deviations regarding measured values in near maintenance fed group [10].

of severe undernutrition (i.e. $20 \% \mathrm{M}$ ), plasma NEFA and 3-hydroxybutyrate concentrations are almost doubled, then they decline regularly in ewes permanently underfed (Fig. 3) showing the ability of Barbarine ewes to adjust the lipid metabolite concentration in order to limit the toxic effects of their high concentrations. This is another part of a general mechanism that tends to spare body lipids and therefore prolongs survival, and/or to alleviate toxic effects of high NEFA and 3-hydroxybutyrate concentrations [16, 19]. In this sense, the Barbarine ewes seem to be more efficient than thintailed ewes, as confirmed by the kinetics of BCS evolution.

\section{BARBARINE SHEEP PRODUCTIONANDNUTRITIONAL CONDITIONS}

\subsection{Numerical productivity of the Barbarine ewe}

Variation in reproductive performance between years has been clearly related to prevailing feeding conditions on natural range grazing $[5,12]$. Two months after ram introduction in May, fertility is significantly lower $(75 \%)$ in lean ewes than in 


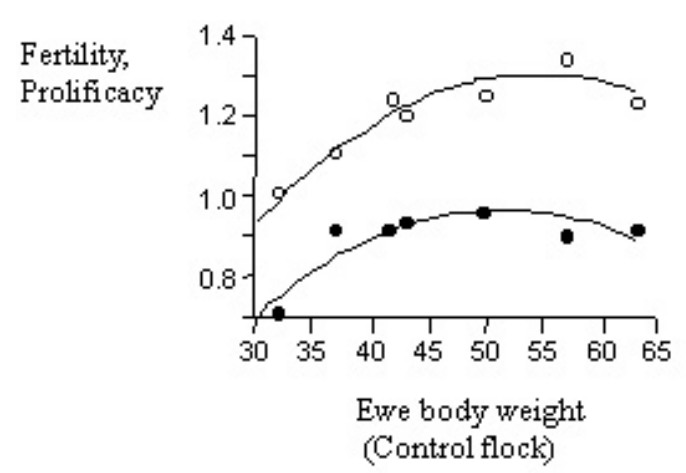

- Fertility oProlificacy

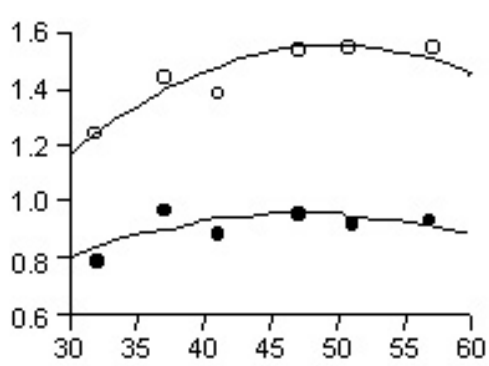

Ewe body weight

(Prolific flock)

- Fertility o Prolificacy

Figure 4. Ewe fertility and prolificacy according to body weight (5 $\mathrm{kg}$ classes) at mating [12].
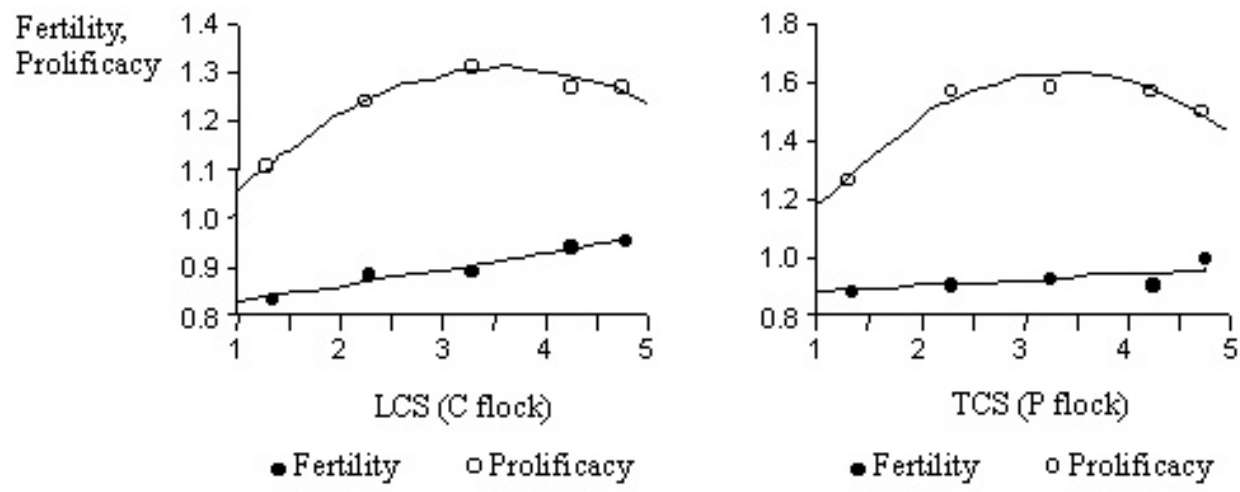

Figure 5. Ewe fertility and prolificacy according to body condition score at mating [12].

those in better body condition (94\%). Extension of the mating period for a further month can improve the fertility of lean ewes up to $87 \%$ if the feeding conditions are fairly good. There is a marked effect of body weight (BW) or body condition score (BCS) on fertility. At a BW less than $35 \mathrm{~kg}$, the fertility was $75 \%$, while at a BCS less than 1.5 the fertility was still $86 \%$ showing that Barbarine ewes' reproductive ability is resistant to underfeeding. There is a curvilinear relationship (Fig. 4) between fertility and $\mathrm{BW}$ while the relationship is linear with BCS (dorsal score or tail size) (Fig. 5), thus illustrating the direct effect of fatness on fertility [12]. This has been confirmed in very low BCS Barbarine ewes that exhibited oestrus behaviour and ovulation after a hormonal treatment [9]. This ability to maintain fertility at a low body condition has already been observed in Mediterranean goats [17], while ewes of temperate areas have a higher BCS threshold $[27,42]$ and reciprocally a higher sensitivity of reproductive performances to feeding conditions.

In Barbarine ewe-lambs, underfeeding between weaning and first mating (18 months) reduces fertility, while re-alimentation of underfed lambs a few months before mating leads to a reproductive performance similar to that of correctly fed ewes (Lassoued, Khaldi and Atti, unpublished data). 
The prolificacy of Barbarine ewes is also affected by body condition, which is a global indicator of their nutritional status. There is a positive curvilinear relationship between prolificacy and BW (Fig. 4) or BCS (Fig. 5) in Barbarine ewes [12], as has been observed previously in Awassi fattailed ewes [46] and thin-tailed ewes [22, 27, 45]. Within the same range of BCS, selected prolific Barbarine ewes [33] exhibit a reduction of $22 \%$ of their prolificacy when underfed, while the prolificacy of unselected ewes (125\%) is not affected by the nutritional status of the ewe. However, in the same nutritional condition, prolific ewes always have a greater prolificacy than normal ewes.

In conclusion, this breed whose prolificacy is quite modest has a good fertility in normal spring feeding conditions. With food shortage before or during the mating period, prolificacy is practically unchanged and the fertility rate is maintained if the mating period can be lengthened.

\subsection{Pregnant ewe, lamb birth weight and mortality}

In the traditional management of mating, Barbarine ewes become pregnant during the summer when feeds can be limited, especially when ewes graze cereal stubble; they are then frequently underfed at this physiological stage [32]. However, this has a limited effect on fotal growth due to the ewes' ability to mobilise body reserves $[1,12,32]$. For instance, it has been shown [34] that Barbarine ewes could lose up to $6.5 \mathrm{~kg} \mathrm{BW}$ between early pregnancy (12 weeks before lambing) and $24 \mathrm{~h}$ after lambing. This mobilisation limits the adverse effect of low nutrition on lamb birth weight and their mortality, without affecting the survival of the dam [6]. Poor nutrition during pregnancy generally has a limited (i.e. non-significant) effect on the birth weight of single lambs of the Barbarine breed (3.4 vs. $3.7 \mathrm{~kg}$, [32]). In the case of a multiple litter, birth weight is significantly affected by dam undernutrition during pregnancy; total litter weight is then diminished (from 4.6 to $3.8 \mathrm{~kg}$; Atti et al., unpublished data) and lamb birth weight is strongly affected (from 3.4 to $2.5 \mathrm{~kg}$, [32]). However, in such conditions, lamb mortality remains low. The mean mortality of lambs in flocks grazing natural ranges in central Tunisia was 5.6\% [23]. The highest mortality rate $(12 \%)$ was observed during a particular drought in a flock only fed with natural grazing; during this year the production of the natural range was very low because rainfall in the late summer and early autumn was less than $50 \mathrm{~mm}$. In theses conditions, the ewes were very lean and their mean BW at lambing was less than $35 \mathrm{~kg}$. Under these conditions, and whenever dam weight exceeds this threshold weight, lamb mortality rate is still limited to 6\% [23]. This low mortality reflected the high ability of the Barbarine ewe to breed its lambs through its ability to continuously lose $\mathrm{BW}$, which has a positive effect on post-natal lamb growth. This effect is, however, generally limited to the first week of lamb's life; in single lambs, the weights $(6.1 \mathrm{~kg})$ at 10 days were similar in lambs bred from underfed ewes and that of correctly fed ewes [32].

\subsection{Lactation and the suckling lamb}

In the same feeding conditions (range grazing), there are different degrees of body reserve mobilisation in $45 \mathrm{~kg}$ suckling ewes at lambing. Ewes mobilising more reserves reached a weaning stage at $30 \mathrm{~kg} \mathrm{BW}$ while those mobilising less had $42 \mathrm{~kg} \mathrm{BW}$ at the same stage. The lamb growth rate is $225 \mathrm{~g}$ per $d$ in offspring issued from higher mobilising ewes vs. $150 \mathrm{~g}$ per $\mathrm{d}$ in those from ewes with a lower mobilisation (Atti et al., unpublished data). The origin of this wide range of abilities to mobilise body reserves is probably due to differences in maternal behaviour of ewes in relationship with its genetic ability to mobilise corporal reserves. So, in harsh nutritional conditions, it would be beneficial to select lambs according to dam reserve mobilising ability. 
Table I. Effect of management type and food supply on Barbarine lamb slaughter body weight (SBW), average daily gain (ADG) and carcass composition [11].

\begin{tabular}{lcccccc}
\hline Management & \multicolumn{3}{c}{ Grazing } & \multicolumn{3}{c}{ Feedlot } \\
\hline Concentrate supply (g) & 200 & 400 & 600 & 200 & 400 & 600 \\
SBW (kg) & 31.1 & 35.2 & 35.7 & 27.4 & 29.8 & 33.0 \\
ADG (g) & 144 & 179 & 178 & 95 & 120 & 152 \\
Muscle (\%) & 59.4 & 56.2 & 57.3 & 54.7 & 53.6 & 51.7 \\
Bone (\%) & 20.8 & 19.9 & 20.3 & 21.3 & 19.6 & 19.7 \\
Fat $(\%)$ & 17.6 & 22.0 & 19.8 & 21.8 & 24.5 & 27.0 \\
\hline
\end{tabular}

For an energetic restriction with a correct nitrogen supply applied for 5 weeks, BW losses can reach $120 \mathrm{~g}$ per d in Barbarine ewes [6] with medium milk potential (approximately $1.5 \mathrm{~L}$ per d or a litter growth rate of $260 \mathrm{~g}$ perd). This loss is even greater, exceeding $150 \mathrm{~g}$ per $\mathrm{d}$, when fatter ewes are subject to undernutrition [34]. This general phenomenon has been observed in thintailed ewes, where BW losses in lactation are positively related $(\mathrm{r}=+0.58 ; P<0.001)$ to the BW at lambing in Aragonesa ewes [31].

The results of an experiment with a cross-over design of the level of food supply in pregnancy and lactation (High-Low, High-High, Low-High, Low-Low) showed that undernutrition during pregnancy has a limited impact on lamb performance but feeding level during lactation has a predominant effect on the growth rate of Barbarine lambs [32]. Litter growth rates on HighHigh and Low-High treatments were similar (143 and $147 \mathrm{~g}$ per d) and higher than those of lambs of ewes on High-Low and Low-Low treatments (97 and $93 \mathrm{~g}$ per d).

\subsection{Weaned lamb performance}

In a favourable year, weaned grazing Barbarine lambs reached a slaughter age (6 months) with a higher weight (Tab. I) than feedlot lambs whatsoever the level of concentrate supply [11]. Furthermore, feedlot lambs have more fat than grazing ones, the fat weight and fat carcass proportion increases with the concentrate level to reach
$27 \%$ in the group receiving $600 \mathrm{~g}$ of concentrate (Tab. I). Under better grazing conditions, lamb growth rate can be improved; this parameter passed from 200 to $260 \mathrm{~g}$ per day (Atti et al., unpublished data).

In very dry years, early weaning (40 to $60 \mathrm{~d}$ of age) of lambs of the Tunisian breeds, i.e., Barbarine, Queue Fine de l'Ouest and Noire de Thibar, and their breeding in feedlots leads to higher performances than keeping them with their mothers at pasture [7] (Tab. II). At the age of 5 months, the BW of lambs in feedlots offered two feeding levels, (high $(\mathrm{H})$ and restricted (R)) was significantly higher than the mean BW $(16 \mathrm{~kg})$ of grazing lambs, which cannot reach the target slaughtering weight in all three breeds. For feedlot lambs, slaughter body weight (SBW) is affected by the feeding level in Queue Fine de l'Ouest and Noire de Thibar breeds but not in Barbarine lambs, which had the same and low SBW with the two feeding levels (Tab. II). This low growth rate in Barbarine sheep resulted from its high adiposity: the carcass fatness was higher in Barbarine than in the two other breeds. This increase is related to the tail fat part since the carcass adiposity without the tail is similar among the 3 breeds (Tab. II).

In lambs with normal birth weight, the post-weaning growth performances of grazing lambs are moderate but in feedlot conditions the food conversion efficiency is low. As a consequence of high fat content and fat accumulation in the tail, the meat of feedlot lambs is of limited consumer 
Table II. Effect of feeding level and breed on lamb slaughter weight (SBW) at 150 days, average daily gain (ADG) and carcass composition in different breeds [7].

\begin{tabular}{lccccccccc}
\hline Breed & \multicolumn{3}{c}{ Barbarine } & \multicolumn{3}{c}{ Queue Fine de l'Ouset } & \multicolumn{3}{c}{ Noire de Tibar } \\
\hline & \multicolumn{3}{c}{ Feedlot } & Grazing $^{\Upsilon}$ & \multicolumn{2}{c}{ Feedlot } & Grazing & Feedlot & Grazing \\
\hline Feeding level & High & Low & & High & Low & & High & Low & \\
SBW (kg) & 20.8 & 19.5 & 16 & 24.4 & 19.4 & 16 & 24.0 & 21.9 & 17 \\
ADG (g) & 117 & 103 & 67 & 148 & 92 & 56 & 143 & 119 & 56 \\
Muscle (\%) & 53.4 & 55.5 & - & 60.2 & 58.6 & - & 61.4 & 60.3 & - \\
Bone (\%) & 18.8 & 20.7 & - & 20.7 & 22.6 & - & 19.5 & 21.2 & - \\
Fat (\%) & 27.8 & 23.8 & - & 16.9 & 15.7 & - & 16.5 & 16.0 & - \\
Without tail & 17.9 & 16.6 & & & & & & & \\
\hline
\end{tabular}

${ }^{\mathrm{r}}$ Sheep were not slaughtered (low BW).

acceptance. This breed seems better adapted to traditional fattening management.

\section{CONCLUSION}

This review shows that the Barbarine sheep, and specially the ewe, is well adapted to the local conditions mainly because of its ability to deposit and mobilise body reserves not only from the tail (fat) but also from the rest of the body (i.e. body fat and body protein). It seems that the lamb is also well adapted to grazing, which is available during a short period (3 to 4 months). This is shown by the modest response to concentrate feeding that is necessary for the fattening of the lambs grazing period. Such a system implies that the ewe's reproduction occurs in the spring, which is quite favourable, but the maximum nutrient demand (pregnancy and lactation) takes place during the summer and early autumn when food is very scarce (stubble, straw). As discussed in this review the main advantage of this ewe is its survival capacity, especially at the non-pregnant and non-lactating stages. Its productivity is rather modest but this ewe is able to produce one lamb per year, with a better growth and fattening response to grazing green forage than to concentrate diets. Furthermore, during the pregnancy when eaten food is limited, the
Barbarine ewe has the capacity to produce one live lamb, while in lactation, sufficient food for a high growth rate of its lamb is needed. Otherwise, at a risk of excessive fatness, the post-weaning growth of its lamb cannot be fully recovered with high amounts of concentrates.

The global productivity of the Barbarine ewe, i.e. the number of lambs per ewe/ year $\times$ lamb slaughter weight, can further be increased by improving its prolificacy. Prolific lines have already been selected in Tunisia. These lines have kept most of the breed's adaptive traits and may offer an increase in productivity on farms. In addition, adequate diet formulation and innovative management practices have to be studied in order to improve lamb growth efficiency.

\section{REFERENCES}

[1] Abdennebi L., Khaldi G., Performances de reproduction d'un troupeau ovin prolifique de race Barbarine, Ann. INRAT 64 (1991) 30.

[2] Atti N., Relations entre l'état corporel et les dépôts adipeux chez la brebis Barbarine, Opt. Méd. Sér. A 13 (1992) 31-34.

[3] Atti N., Bocquier F., Nefzaoui A., Thériez M., Effects of undernutrition in dry Barbarine ewes on digestibility, nitrogen balance, live weight and body condition changes, FAOCIHEAM-EC Meeting on Sheep and Goat Nutrition, Thessaloniki, 1993. 
[4] Atti N., Bocquier F., Khaldi G., Thériez M., Localisation et importance des différents dépôts adipeux selon l'état corporel chez des brebis à queue grasse, Ann. Zootech. 42 (1993) 214-215.

[5] Atti N., Abdennabi L., État corporel et performances de la race ovine Barbarine, Opt. Méd. 6 (1995) 75-80.

[6] Atti N., Bocquier F., Nefzaoui A., Influence de l'état corporel à la mise bas sur les performances, le bilan énergétique et l'évolution des métabolites sanguins de la brebis Barbarine, Opt. Méd. Sér. A (1995) 25-33.

[7] Atti N., Abdouli H., Effets du niveau alimentaire et de la race sur la croissance et la qualité de carcasses des agneaux, Opt. Méd. Sér. A (1997) 195-198.

[8] Atti N., Bocquier F., Adaptation des brebis Barbarine à l'alternance sous-nutrition-réalimentation : effets sur les tissus adipeux, Ann. Zootech. 48 (1999) 189-198.

[9] Atti N., Capacité d'adaptation de la brebis Barbarine aux conditions alimentaires difficiles : importance des réserves corporelles et des adaptations digestives, Thèse de Doctorat d'Etat, INAT, Université de Tunis, 2000, $200 \mathrm{p}$.

[10] Atti N., Nozière P., Doreau M., Kayouli C., Bocquier F., Effects of underfeeding and refeeding on offal weight in the Barbarine ewes, Small Rum. Res. 38 (2000) 37-43.

[11] Atti N., Abdouli H., Effets du niveau du concentré sur les performances bouchères des agneaux de race Barbarine conduits au pâturage ou en bergerie, Ann. INRAT 74 (2001) 151-163.

[12] Atti N., Thériez M., Abdennebi L., Relationship between ewe body condition at mating and reproductive performance in the fat-tailed Barbarine breed, Anim. Res. 50 (2001) 135144.

[13] Bocquier F., Thériez M., Sheep in ruminant nutrition, in: Jarrige R. (Ed.), Ruminant Nutrition: Recommended Allowances and Feed Tables, INRA Editions, 1990, pp. 153-165.

[14] Bocquier F., Chilliard Y., Effect of severe undernutrition on body weight and fat tissue changes in dry Lacaune ewes, Ann. Zootech. 43 (1994) 300.

[15] Bocquier F., Guillouet Ph., Barillet F., Alimentation hivernale des brebis laitières : intérêt de la mise en lots, Prod. Anim. (INRA) 8 (1995) 19-28.

[16] Bocquier F., Atti N., Purroy A., Chilliard Y., The role of body reserves in the metabolic adaptation of different breeds of sheep to food shortage, in: Guessous F., Rihani N., Ilham A.
(Eds.), Proceeding of symposium on Livestock production and climatic uncertainly in the Mediterranean, EAAP Publ. 94 (2000) 7593.

[17] Branca A., Casu S., Évolution de l'état corporel au cours de l'année et sa relation avec le niveau des dépôts adipeux chez la chèvre Sarde, Symposium « Philoetios » sur l'évaluation des ovins et des caprins Méditerranéens, rapport Agrimed EUR 11893 FR-EN, 1989, pp. 221-236.

[18] Butler-Hogg B.W., Wood J.D., Bines J.A., Fat partitioning in british Friesian cows: the influence of physiological state on dissected body composition, J. Agric. Sci. (Camb.) 104 (1985) 519-528.

[19] Chilliard Y., Doreau M., Bocquier F., Lobley G.E., Digestive and metabolic adaptations of ruminants to variations in food supply. In Recent developments in the nutrition of herbivores, in: Journet M., Grenet E., Farce M.H., Thériez M., Demarquilly C. (Eds.), Proceedings of the IVth International Symposium on the Nutrition of Herbivores, INRA Editions, Paris, 1995, pp. 329-360.

[20] Chilliard Y., Bocquier F., Doreau M., Digestive and metabolic adaptations of ruminants to undernutrition, and consequences on reproduction, Reprod. Nutr. Dev. 38 (1998) 131152.

[21] Chilliard Y., Ferlay A., Despres L., Bocquier F., Plasma non esterified fatty acid response to a beta-adrenergic challenge before or after feeding in energy underfed or overfed, dry or lactating cows, Anim. Sci. 67 (1998) 213 223.

[22] Coop I.E., Effect of flushing on reproductive performance of ewes, J. Agric. Sci. (Camb.) 67 (1966) 305-323.

[23] Daldoul A., Analyse de la mortalité des agneaux de race Barbarine, Mémoire de fin d'études, ESA Mateur Université de Tunis, 1995, 67 p.

[24] Epstein H., The Awassi sheep with special reference to the improved dairy type, FAO Anim. Prod. Health Paper 57 (1985) 282.

[25] Galal E.S.E., Strategies for the genetic improvement of fat-tail sheep in the Near East, in: Strategies for the development of fat-tail sheep in the Near East, EAAP Publ. 68 (1994) 13-20.

[26] Guessous F., Boudjenane I., Bourfia M., Narjisse H., Sheep in Marocco, in: Small ruminant in the Near East, Vol. III, North Africa FAO, Anim. Prod. Health. Paper 74 (1989) 1-95.

[27] Gunn R.G., Doney J.M., Russel A.J.M., Fertility in Scottish Blackface ewes as influenced 
by nutrition and body condition at matting, $\mathrm{J}$. Agric. Sci. (Camb.) 73 (1969) 289-294.

[28] Hafez E.S.E., Studies on the breeding season on reproduction of the ewe, J. Agric. Sci. 42 (1952) 189-565.

[29] Hafez E.S.E., Oestrus activity in fat-tailed sheep during the longest days, Experientia 8 (1954) 338-340.

[30] Hight G.K., Barton R.A., The effects of undernutrition and re-alimentation on the Romney ewe, J. Agric. Sci. (Camb.) 64 (1965) 413424.

[31] Jaime C., Purroy A., Level and quality of protein in rations for lactating ewes, Ann. Zootech. 44 (1995) 135-142.

[32] Khaldi G., Influence du niveau alimentaire en fin de gestation et pendant la lactation sur la production laitière de la brebis Barbarine et la croissance de l'agneau de race Barbarine en année sèche, Ann. INRAT 56 (1983) 32.

[33] Khaldi G., Atti N., Étude génétique de la croissance et résultats de sélection sur la prolificité chez la race Barbarine, in : Séminaire sur le développement des productions ovines et caprines dans le centre de la Tunisie, Kairouan (Tunisie), 27-28 Mars 1987.

[34] Khaldi G., Barbarine sheep, in: Small ruminant in the Near East, Vol. III, North Africa FAO, Anim. Prod. Health. Paper 74 (1989) 96-135.

[35] Le Houérou H.N., Recherches expérimentales sur la tolérance du mouton Barbarin à l'inanition et la restriction alimentaire, in: Le Floch E., Grouzis M., Cornet A., Bille J.C. (Eds.), L'aridité : contrainte au développement, Orstom éditions, 1992, pp. 369-385.

[36] OEP, Aperçu sur les activités de l'OEP en matière d'élevage ovin : Campagnes 1991-92 et 1992-93, Direction de l'élevage, Office de l'Élevage et des Pâturages, Ministère de l'Agriculture, Tunis, 1994.

[37] Ortigues I., Doreau M., Responses of splanchnic tissues of ruminants to changes in intake: absorption of digestion end products, tissue mass, metabolic activity and implications to whole animal energy metabolism, Ann. Zootech. 44 (1995) 321-346.

[38] Panaretto B.A., Body composition in vivo, VI The composition of ewes during prolonged undernutrition, Aust. J. Agric. Res. 15 (1964) 771-787.

[39] Robelin J., Agabriel J., Malterre C., Bonnemaire J., Changes in body composition of mature dry cows of Holstein, Limousin, and Charolais breeds during fattening. I. Skeleton, muscles, fatty tissues and offal, Livest. Prod. Sci. 25 (1990) 199-215.

[40] Robinson T.J., Moore N.W., Linsday D.R., Fletcher I.C., Salamon S., Fertility following synchronisation of oestrus in the sheep whith intravaginal sponges, Aust. J. Agric. Res. 21 (1970) 767-781.

[41] Russel A.J.F., Doney J.M., Gunn R.G., Subjective assessment of body fat in live sheep, $\mathrm{J}$. Agric. Sci. 72 (1969) 451-454.

[42] Russel A.J.F., Means of assessing the adequacy of nutrition of pregnant ewes, Livest. Prod. Sci. 11 (1984) 429-439.

[43] Sarson M., Les ovins dans l'antiquité d'après les vestiges phéniciens et romains en Tunisie et en Algérie, Doc. Tech. INRAT 65 (1973) 30.

[44] Teixeira A., Delfa R., Colomer Rocher F., Relationships between fat depots and body condition score or tail fatness in the Rasa Aragonesa breed, Anim. Prod. 49 (1989) 275280.

[45] Thériez M., Influence de l'alimentation sur les performances de reproduction des ovins, in:

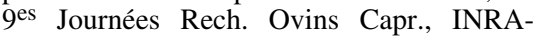
ITOVIC, 1984, pp. 294-326.

[46] Thomson E.F., Bahadi F.A., A note of the effect of liveweight at mating on fertility of Awassi in semi-arid north west Syria, Anim. Prod. 47 (1988) 505-508. 